Check for updates

Cite this: RSC Adv., 2019, 9, 17391

Received 13th March 2019

Accepted 27th May 2019

DOI: 10.1039/c9ra01909j

rsc.li/rsc-advances

\section{Copper-catalyzed intramolecular cross dehydrogenative coupling approach to coumestans from 2'-hydroxyl-3-arylcoumarins $\uparrow$}

\author{
Xianheng Song, ${ }^{a}$ Xiang Luo, ${ }^{a}$ Jianfei Sheng, ${ }^{a}$ Jianheng Li, ${ }^{a}$ Zefeng Zhu, ${ }^{a}$ Zhibo Du, \\ Hui Miao, ${ }^{a}$ Meng Yan, ${ }^{a}$ Mingkang $\mathrm{Li}^{\mathrm{a}}$ and Yong Zou (D) *ab
}

A copper-catalyzed intramolecular cross dehydrogenative $\mathrm{C}-\mathrm{O}$ coupling reaction of $2^{\prime}$-hydroxyl-3arylcoumarins was developed. This protocol provided a facile and efficient strategy for the construction of natural coumestans and derivatives in moderate to high yields. This transformation exhibited good functional group compatibility and was amenable to substrates with free phenolic hydroxyl groups.

\section{Introduction}

Coumestans are an important class of naturally occurring tetracyclic lactones with diverse biological properties and represent a valuable class of lead compounds for drug discovery. ${ }^{1}$ For example, wedelolactone, coumestrol, aureol, medicagol and flemichapparin $\mathrm{C}$ are all naturally occurring coumestans exhibiting a broad spectrum of activities including anticancer, antibacterial, antifungal, antiosteoporosis, antihepatotoxic, antioxidative, estrogenic and neuroprotective effects. ${ }^{2}$ Accordingly, coumestan derivatives have received significant attention and many synthetic approaches have been reported in the past decades. $^{3-6}$ In 2016, McGlacken and $\mathrm{Xu}$ independently described a $\mathrm{Pd}(\mathrm{OAc})_{2} / \mathrm{Ag}_{2} \mathrm{O}$ and $\mathrm{Pd}(\mathrm{OAc})_{2} / \mathrm{AgOAc}$ co-catalyzed intramolecular cross dehydrogenative $\mathrm{C}-\mathrm{C}$ coupling reaction of 4-phenoxy-2-coumarins to provide coumestans and derivatives (Scheme 1)..$^{3 a j}$ These double $\mathrm{C}-\mathrm{H}$ activation methods represented a rapid and efficient access to coumestans. Gogoi disclosed a palladium-catalyzed cascade $[3+2]$ reaction of 4 hydroxycoumarins and in situ generated arynes ${ }^{3 b}$ to give coumestans; this protocol is attractive in terms of atom economy. Tromp and McGlacken independently developed a palladiumcatalyzed intramolecular $\mathrm{C}-\mathrm{H}$ bond functionalization method by using preformed ortho-halogenated coumaryl ethers as starting materials. ${ }^{3 c, 3 i}$ Zhao reported a $\mathrm{FeCl}_{3}$-mediated direct intramolecular oxidative annellation protocol using 4-hydroxy3 -arylcoumarins, ${ }^{3 d}$ which is probably the most straightforward strategy for constructing coumestans. Pappo and Tang

${ }^{a}$ School of Pharmaceutical Sciences, Sun Yat-sen University, Guangzhou 510640, P. R. China.E-mail: zou_jinan@163.com

${ }^{b}$ Zhongshan WanHan Pharmceutical Co., Ltd, Zhongshan 528451, P. R. China $\dagger$ Electronic supplementary information (ESI) available: Detailed experimental procedures, ${ }^{1} \mathrm{H}$ and ${ }^{13} \mathrm{C}$ NMR data and spectra. CCDC 1552229. For ESI and crystallographic data in CIF or other electronic format see DOI: 10.1039/c9ra01909j respectively offered a $\mathrm{BBr}_{3}$-mediated tandem demethylation/ lactonization reaction of 3-carboxylated benzofurans ${ }^{3 e}$ or 2,3bis(2-methoxyphenyl)-3-oxopropanals to form the coumestan nucleus (pyridinium dichromate was further needed to afford final coumestans in Tang's work). ${ }^{3 g}$ Larock developed a palladium-catalyzed CO insertion (carbonylation) of 3-iodobenzofurans, followed by lactonization to afford coumestans. ${ }^{3 h}$ Most recently, based on Nogami and his own early work, Tilve reported an oxidative cyclization method of 3-(2-hydroxyphenyl) coumarins promoted by stoichiometric amount of $\mathrm{Cu}(\mathrm{OAc})_{2}$ in diphenyl ether at $258^{\circ} \mathrm{C} .{ }^{3 k, 3 l, 3 m}$ Although great progress has been made, the above-mentioned methods still suffer from disadvantages such as the necessity of expensive palladium catalysts, pre-halogenated or specified substrates, the use of excess amount of the corrosive $\mathrm{BBr}_{3}$ and environmentally hazardous chromium-containing oxidant, as well as the need of extremely high reaction temperature. Therefore, the development of a general strategy that is facile, efficient, noble metal-free and

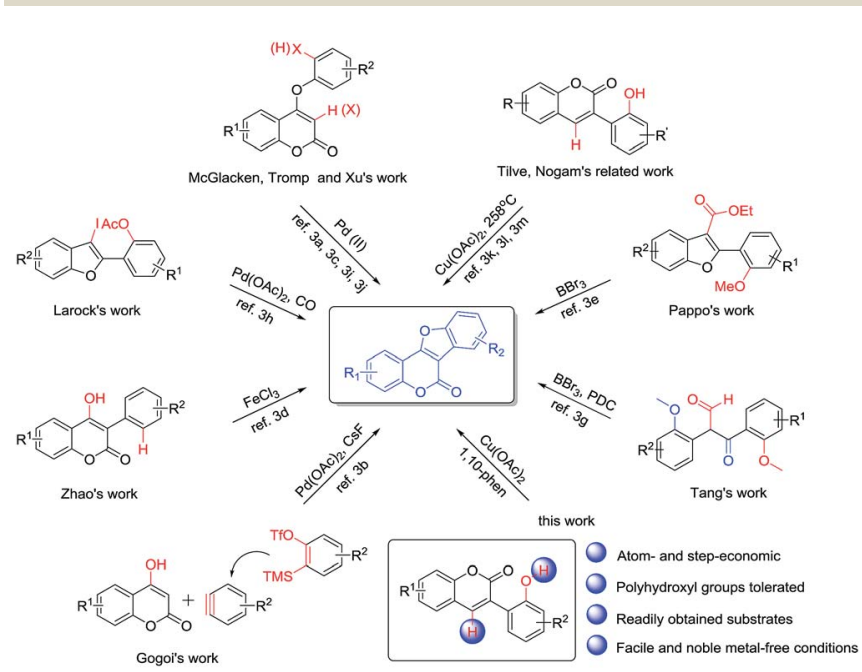

Scheme 1 Strategies to coumestans. 


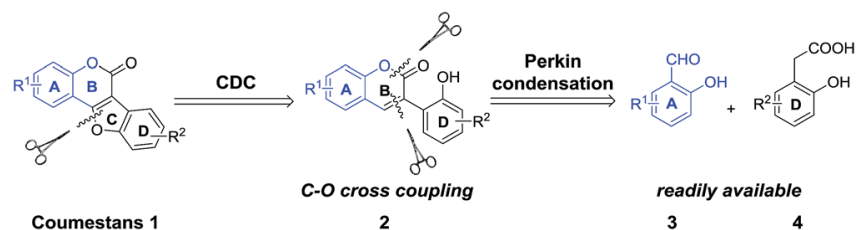

Scheme 2 Retrosynthetic analysis of coumestans 1.

compatible with polyphenolic substrates for the synthesis of coumestans would still be desired.

Cross coupling reactions for $\mathrm{C}-\mathrm{O}$ bond formation are among the most important organic transformations because they provide key steps in building new and complex compounds either in inter- or intramolecular manner. ${ }^{7}$ In recent years, transition-metal catalyzed $\mathrm{C}-\mathrm{H}$ bond activation and subsequent $\mathrm{C}-\mathrm{O}$ bond formation represent a powerful tool for the modular and facile synthesis of oxygen-containing aromatic heterocycles,${ }^{8}$ such as benzoxazoles,${ }^{8 a}$ dibenzofurans ${ }^{8 b}$ benzoxazines ${ }^{8 c}$ oxazinones ${ }^{8 d}$ and oxadiazoles. ${ }^{8 e}$ We envisaged that the coumestan motif could be effectively constructed through intramolecular cross dehydrogenative $\mathrm{C}-\mathrm{O}$ coupling reaction of $2^{\prime}$ hydroxyl-3-arylcoumarins (2), which could be readily obtained through Perkin condensation between ortho-hydroxybenzaldehydes (3) and 2-hydroxyphenylacetic acids (4) (Scheme 2). As part of our continuing efforts on the green synthesis of natural products with $\mathrm{C} 6-\mathrm{C} 2-\mathrm{C} 6$ and $\mathrm{C6}-\mathrm{C} 3-\mathrm{C} 6$ frameworks, ${ }^{9}$ we herein report a facile, efficient, noble metalfree and polyphenolic group tolerated strategy for the synthesis of coumestans.

\section{Results and discussion}

Initially, 2', $4^{\prime}$-dihydroxyl-3-arylcoumarin (2a) was synthesized through Perkin condensation and used as the model substrate for the study of reaction conditions (Table 1). To our delight, the $\mathrm{C}-\mathrm{O}$ dehydrogenative coupling reaction of $2 \mathrm{a}$ took place in DMSO at $135{ }^{\circ} \mathrm{C}$ catalyzed by 0.2 equiv. of $\mathrm{Cu}(\mathrm{OAc})_{2} / 1,10$-phen, affording the desired product 1a in 56\% yield (Table 1, entry 1). Then, a series of commonly used solvents were examined. Results showed that DMF and glycol were unworkable with no 1a detected (entries 2 and 3). However, when $p$-xylene was used, 1a was obtained in $69 \%$ yield (entry 4 ). Interestingly, when the reaction was performed in $\mathrm{DMSO} / \mathrm{H}_{2} \mathrm{O}(3: 1, \mathrm{v} / \mathrm{v})$, a $78 \%$ yield was obtained (entry 5). Further screening of the solvent ratio revealed that $\mathrm{DMSO} / \mathrm{H}_{2} \mathrm{O}(3: 1, \mathrm{v} / \mathrm{v})$ gave the best result, whereas the $1: 1,2: 1$ or $4: 1(\mathrm{v} / \mathrm{v})$ solvent ratio was less effective (compare entries 5-8). Subsequently, different oxidants were investigated, reaction performed under air gave similar result as under oxygen atmosphere (compare entries 5 and 9), other oxidants such as DTBP, TBHP, $\mathrm{AgOAc}, \mathrm{Ag}_{2} \mathrm{CO}_{3}$ and $\mathrm{Cu}(\mathrm{OAc})_{2}$ in 2-3 equivalent amount respectively, could also promote the reaction, but lower yields were obtained (entries 10-14). The choice of 1,10-phen as ligand was crucial for this reaction, other

Table 1 Optimization of the catalytic conditions ${ }^{a}$

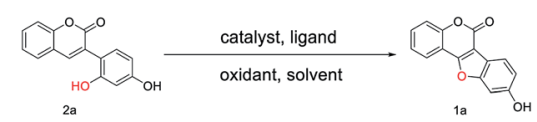

\begin{tabular}{|c|c|c|c|c|c|}
\hline Entry & $\begin{array}{l}\text { Catalyst ( } 0.2 \\
\text { equiv.) }\end{array}$ & Ligand ( 0.2 equiv.) & Oxidant & Solvent & Yield $^{b}(\%)$ \\
\hline 1 & $\mathrm{Cu}(\mathrm{OAc})_{2}$ & 1,10-Phen & Air & DMSO & 56 \\
\hline 2 & $\mathrm{Cu}(\mathrm{OAc})_{2}$ & 1,10-Phen & Air & DMF & $\mathrm{ND}^{c}$ \\
\hline 3 & $\mathrm{Cu}(\mathrm{OAc})_{2}$ & 1,10-Phen & Air & Glycol & $\mathrm{ND}^{c}$ \\
\hline 4 & $\mathrm{Cu}(\mathrm{OAc})_{2}$ & 1,10-Phen & Air & p-xylene & 69 \\
\hline 5 & $\mathrm{Cu}(\mathrm{OAc})_{2}$ & 1,10-Phen & Air & $\mathrm{DMSO} / \mathrm{H}_{2} \mathrm{O}(3: 1)$ & 78 \\
\hline 6 & $\mathrm{Cu}(\mathrm{OAc})_{2}$ & 1,10-Phen & Air & $\mathrm{DMSO} / \mathrm{H}_{2} \mathrm{O}(1: 1)$ & Trace \\
\hline 7 & $\mathrm{Cu}(\mathrm{OAc})_{2}$ & 1,10-Phen & Air & $\mathrm{DMSO} / \mathrm{H}_{2} \mathrm{O}(2: 1)$ & 32 \\
\hline 8 & $\mathrm{Cu}(\mathrm{OAc})_{2}$ & 1,10-Phen & Air & $\mathrm{DMSO} / \mathrm{H}_{2} \mathrm{O}(4: 1)$ & 53 \\
\hline 9 & $\mathrm{Cu}(\mathrm{OAc})_{2}$ & 1,10-Phen & $\mathrm{O}_{2}$ & $\mathrm{DMSO} / \mathrm{H}_{2} \mathrm{O}(3: 1)$ & 78 \\
\hline $10^{d}$ & $\mathrm{Cu}(\mathrm{OAc})_{2}$ & 1,10-Phen & $\mathrm{DTBP}^{e}$ & $\mathrm{DMSO} / \mathrm{H}_{2} \mathrm{O}(3: 1)$ & 19 \\
\hline $11^{d}$ & $\mathrm{Cu}(\mathrm{OAc})_{2}$ & 1,10-Phen & $\mathrm{TBHP}^{f}$ & $\mathrm{DMSO} / \mathrm{H}_{2} \mathrm{O}(3: 1)$ & 23 \\
\hline $12^{d}$ & $\mathrm{Cu}(\mathrm{OAc})_{2}$ & 1,10-Phen & $\mathrm{AgOAc}^{g}$ & $\mathrm{DMSO} / \mathrm{H}_{2} \mathrm{O}(3: 1)$ & Trace \\
\hline $13^{d}$ & $\mathrm{Cu}(\mathrm{OAc})_{2}$ & 1,10-Phen & $\mathrm{Ag}_{2} \mathrm{CO}_{3}{ }^{h}$ & $\mathrm{DMSO} / \mathrm{H}_{2} \mathrm{O}(3: 1)$ & Trace \\
\hline $14^{d}$ & $\mathrm{Cu}(\mathrm{OAc})_{2}{ }^{i}$ & 1,10-Phen & - & $\mathrm{DMSO} / \mathrm{H}_{2} \mathrm{O}(3: 1)$ & Trace \\
\hline 15 & $\mathrm{Cu}(\mathrm{OAc})_{2}$ & Bipyridine & Air & $\mathrm{DMSO} / \mathrm{H}_{2} \mathrm{O}(3: 1)$ & Trace \\
\hline 16 & $\mathrm{Cu}(\mathrm{OAc})_{2}$ & Triethylamine & Air & $\mathrm{DMSO} / \mathrm{H}_{2} \mathrm{O}(3: 1)$ & $\mathrm{ND}^{c}$ \\
\hline 17 & $\mathrm{Cu}(\mathrm{OAc})_{2}$ & Proline & Air & $\mathrm{DMSO} / \mathrm{H}_{2} \mathrm{O}(3: 1)$ & $\mathrm{ND}^{c}$ \\
\hline 18 & $\mathrm{CuI}$ & 1,10-Phen & Air & $\mathrm{DMSO} / \mathrm{H}_{2} \mathrm{O}(3: 1)$ & 76 \\
\hline 19 & $\mathrm{Cu}_{2} \mathrm{O}$ & 1,10-Phen & Air & $\mathrm{DMSO} / \mathrm{H}_{2} \mathrm{O}(3: 1)$ & Trace \\
\hline 20 & $\mathrm{Cu}(\mathrm{OTf})_{2}$ & 1,10-Phen & Air & $\mathrm{DMSO} / \mathrm{H}_{2} \mathrm{O}(3: 1)$ & 67 \\
\hline 21 & $\mathrm{Cu}(\mathrm{TFA})_{2}$ & 1,10-Phen & Air & $\mathrm{DMSO} / \mathrm{H}_{2} \mathrm{O}(3: 1)$ & Trace \\
\hline
\end{tabular}

${ }^{a}$ Reaction conditions: $2 \mathrm{a}(1 \mathrm{mmol})$, catalyst $(0.2 \mathrm{mmol})$, ligand $(0.2 \mathrm{mmol})$ and an oxidant in a specific solvent $(4 \mathrm{~mL})$ at $135{ }^{\circ} \mathrm{C}$ for $18 \mathrm{~h} .{ }^{b}$ Isolated yield. ${ }^{c}$ No desired product. ${ }^{d}$ The reaction was performed under argon. ${ }^{e}$ DTBP (3.0 equiv.) was added. ${ }^{f}$ TBHP (3.0 equiv.) was used. ${ }^{g}$ AgOAc (2.0 equiv.) was used. ${ }^{h} \mathrm{Ag}_{2} \mathrm{CO}_{3}$ (2.0 equiv.) was used. ${ }^{i} \mathrm{Cu}(\mathrm{OAc})_{2}$ (2.0 equiv.) was used. 
ligands, such as bipyridine, triethylamine and proline were unworkable in this transformation (entries 15-17). In addition, a screening of catalysts revealed that $\mathrm{Cu}(\mathrm{OAc})_{2}$ gave the best results in this reaction, while $\mathrm{CuI}$ or $\mathrm{Cu}(\mathrm{OTf})_{2}$ was also applicable (entries 18, 20). However, $\mathrm{Cu}_{2} \mathrm{O}$ and $\mathrm{Cu}(\mathrm{TFA})_{2}$ were found to be inferior, giving only trace amount of desired product 1a (entries 19, 21). Therefore, the optimal conditions for the synthesis of coumestans via intramolecular cross dehydrogenative $\mathrm{C}-\mathrm{O}$ coupling reaction were as follows: $2 \mathrm{a}$ (1.0 equiv.) and $\mathrm{Cu}(\mathrm{OAc})_{2} / 1,10$-phen ( 0.2 equiv.) in $\mathrm{DMSO} / \mathrm{H}_{2} \mathrm{O}(3: 1, \mathrm{v} / \mathrm{v})$ were stirred at $135{ }^{\circ} \mathrm{C}$ under air.

With the optimized reaction conditions in hand, we then probed the generality of this methodology for the synthesis of diverse coumestans (Table 2). Satisfyingly, this intra-molecular oxidative $\mathrm{C}-\mathrm{O}$ forming reaction displayed good functional group tolerance. Substrates bearing different groups on the D ring, such as -OH, -OMe, 3,4-dimethoxyl, 3,4,5-trimethoxyl, 3,4methylenedioxyl were examined and all of them reacted smoothly to give the desired products in moderate to high yields (Table 2, 1a-f). Substrate with a naphthyl group (2g) also successfully led to the desired product $1 \mathrm{~g}$ in $70 \%$ yield. Moreover, substrates with $-\mathrm{OH},-\mathrm{Me},-\mathrm{OMe}$, dimethoxyl, $-\mathrm{Cl}$ on the A ring also performed well, furnishing the desired coumestans 1h-r in $37-87 \%$ yields. It is worth noting that this transformation exhibited good polyhydroxyl group tolerance, substrates bearing two phenolic hydroxy groups either on ring A

Table 2 Scope of the reaction ${ }^{a, b}$

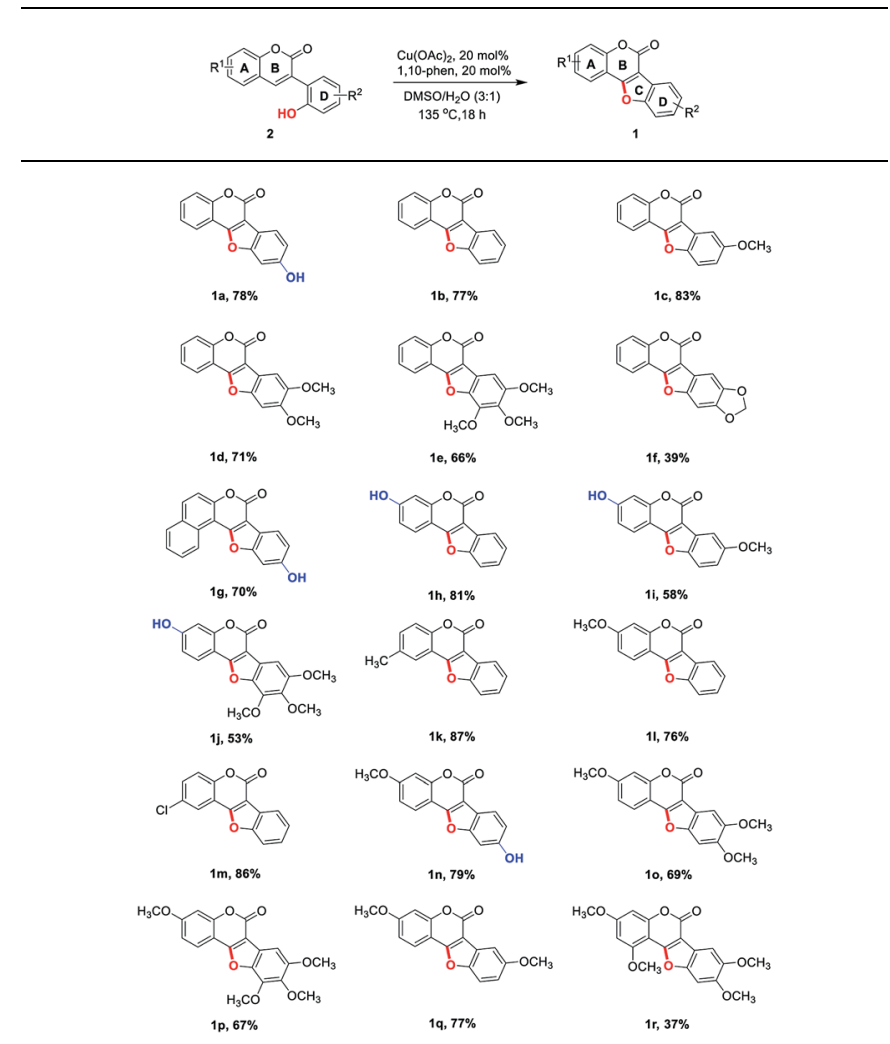

${ }^{a}$ The reactions were carried out as follows: 3-arylcoumarins (2, 1.0 $\mathrm{mmol}), \mathrm{Cu}(\mathrm{OAc})_{2}(20 \mathrm{~mol} \%)$ and 1,10 -phen $(20 \mathrm{~mol} \%)$ in $\mathrm{DMSO} / \mathrm{H}_{2} \mathrm{O}$ $(\mathrm{v} / \mathrm{v}=3: 1)$ at $135{ }^{\circ} \mathrm{C}$ for $18 \mathrm{~h}$ under air atmosphere. ${ }^{b}$ Isolated yields. or ring D smoothly provided $\mathbf{1 a}, \mathbf{1 g}, \mathbf{1 h}, \mathbf{1 i}, \mathbf{1 j}, \mathbf{1 n}$ in acceptable yields (53-81\%). Furthermore, the structural correctness of these products was unambiguously confirmed by the X-ray single crystal analysis of 1e (Fig. 1). ${ }^{10}$

To explore the synthetic utility of this copper-catalyzed intramolecular $\mathrm{C}-\mathrm{O}$ forming protocol, the synthesis of natural coumestans, coumestrol (1s) and 9-methoxy-coumestrol (1t) has been carried out. As shown in Scheme 3, $m$-bromophenol (8) reacted with glyoxylic acid in aqueous $\mathrm{NaOH}$ successfully gave 2bromo-4-hydroxymandelic acid (7) in 92\% yield. Reduction of 7 using $\mathrm{SnCl}_{2} / \mathrm{HCl}$ afforded 2-bromo-4-hydroxyphenylacetic acid (5s) in $80 \%$ yield. Then 2,4- dihydroxyphenylacetic acid (4s) could be readily obtained through hydroxylation in the presence of oxine-copper/NaOH, whereas 2-hydroxy-4methoxyphenylacetic acid (4t) was obtained via $\mathrm{Me}_{2} \mathrm{SO}_{4}$ methylation followed by oxine-copper/NaOH hydroxylation. Subsequently, Perkin condensation of $4 \mathbf{s}+3 \mathbf{b}$ and $4 \mathbf{t}+3 \mathbf{b}$ gave $2^{\prime}, 7-$ diacetylated 3-arylcoumarin intermediates $9 \mathbf{s}$ and 9 t. Deacetylation of $9 \mathrm{~s}$ and $9 \mathrm{t}$ in $10 \%$ aqueous $\mathrm{NaOH}$ followed by acidification with diluted $\mathrm{HCl}$ respectively provided the 2'-hydroxyl-3arylcoumarin intermediates (2s, 2t) in $91 \%$ and $89 \%$ yields. Finally, coumestrol (1s) and 9-methoxy-coumestrol (1t) were achieved under our optimized reaction conditions in $48 \%$ and $63 \%$ yields, respectively.Inspired by the above results, we then turned our attention towards the synthesis of three other natural coumestans, namely 8,9-dimethoxy-coumestrol (1u), medicagol (1v), and flemichapparin $\mathrm{C}(\mathbf{1 w})$. As illustrated in Scheme $4 \mathrm{~A}$ and $4 \mathrm{~B}$, starting from phenylacetic acids (6u and $\mathbf{6 v}$ ),

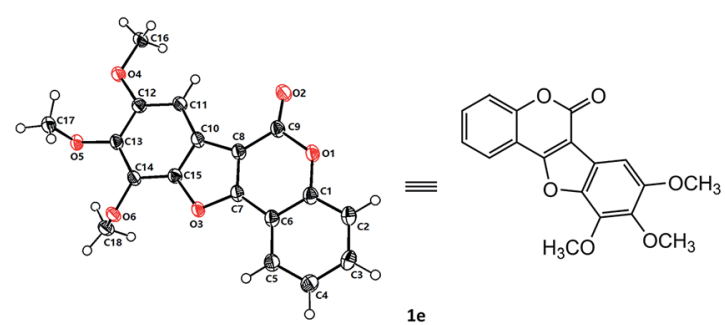

Fig. 1 X-ray single crystal structure of $1 \mathrm{e}$.

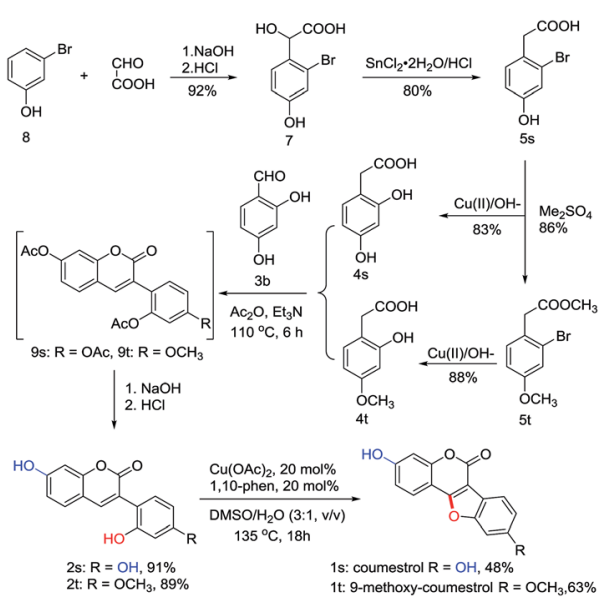

Scheme 3 Synthesis of coumestrol (1s) and 9-methoxy-coumestrol (1t). 
(A)

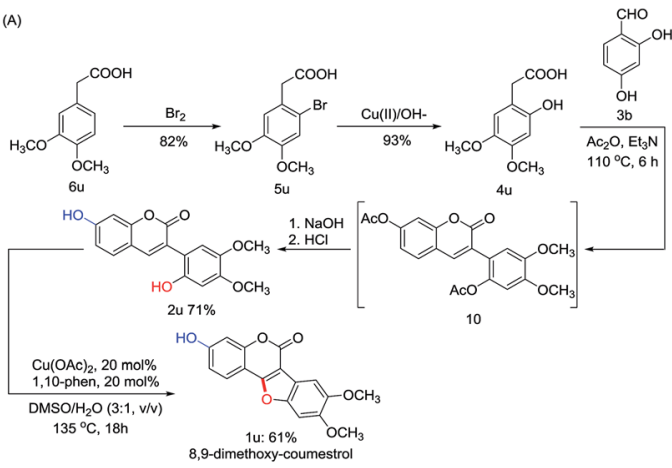

(B)

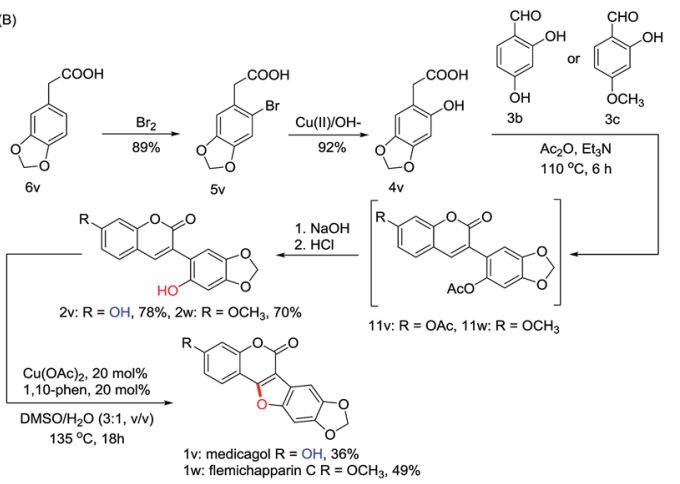

Scheme 4 Synthesis of 8,9-dimethoxy-coumestrol (1u), medicagol (1v) and flemichapparin C (1w).

the ortho- hydroxylated phenylacetic acid intermediates ( $4 \mathbf{u}$ and 4v) could be obtained through bromination and hydroxylation. Perkin condensation of $4 \mathbf{u}+3 \mathbf{b}, \mathbf{4 v}+\mathbf{3 b}$, and $\mathbf{4 v + 3 c}$ successfully provided acetylated 3-arylcoumarin intermediates $(\mathbf{1 0}, \mathbf{1 1 v}$, and 11w) which could then be deacetylated in $10 \%$ aqueous $\mathrm{NaOH}$, and acidified with diluted $\mathrm{HCl}$ to afford the corresponding $2^{\prime}$ hydroxyl-3-arylcoumarin intermediates $(2 \mathbf{u}, 2 \mathbf{v}$, and $2 \mathbf{w})$ in $71 \%$, $78 \%$, and $70 \%$ yields. Finally, the 8,9-dimethoxy-coumestrol (1u), medicagol (1v) and flemichapparin C (1w) were assembled under optimized conditions in $61 \%, 36 \%$, and $49 \%$ yields, respectively.

To gain more insight into the effect of water in the solvent of this protocol, control experiments were carried out by using $2 \mathbf{j}$ as substrate (Scheme 5). As expected, the reaction performed smoothly under the standard conditions, affording the desired
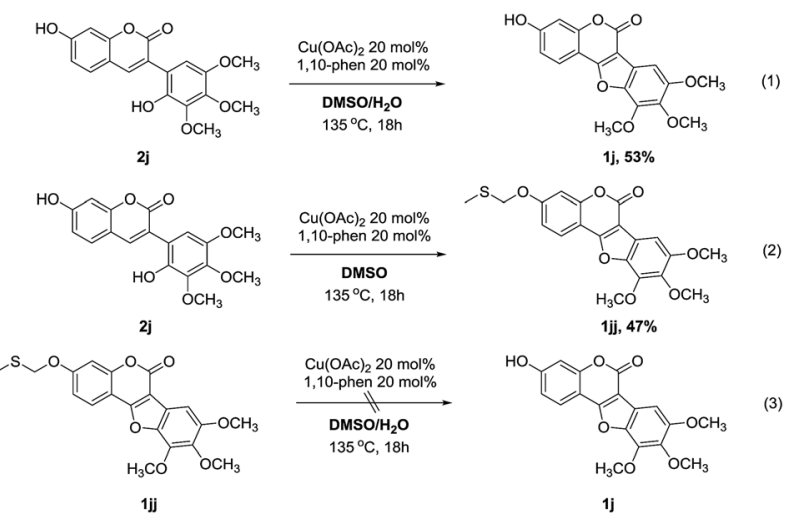

Scheme 5 Control experiments.

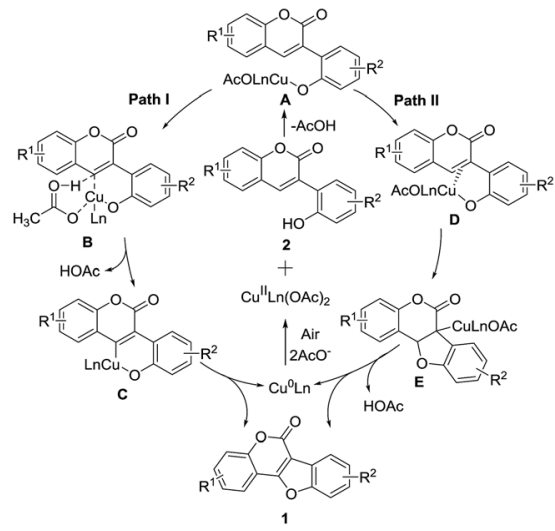

Scheme 6 Possible mechanistic pathway.

coumestan product $\mathbf{1} \mathbf{j}$ in $53 \%$ yield (eqn (1)). However, when anhydrous DMSO was used as the solvent, an interesting methylthiomethyl ether product (1jj) was obtained in $47 \%$ yield (eqn (2)). Interestingly, 1jj could not proceed to afford the desired product $\mathbf{1} \mathbf{j}$ under the standard conditions (eqn (3)). These results suggested that $\mathbf{1} \mathbf{j j}$ might not be the intermediate of the reaction and the effect of water in the reaction is probably coming from the inhibition of the methylthiomethyl functionalization of hydroxyl group. ${ }^{\mathbf{1 1}}$

To further explore the reaction mechanism, the electron paramagnetic resonance (EPR) experiment was carried out by using $\mathbf{2 a}$ as the substrate. Results showed that no obvious EPR signals were observed in the reaction mixture (see Scheme S1 $\dagger$ ). Moreover, it was also found that the addition of the typical radical scavengers including TEMPO and BHT (3.0 equiv.) did not significantly reduce the yields of this reaction, the desired product (1a) was obtained in $68 \%$ and $59 \%$ yields, respectively (see Scheme $\mathrm{S} 2 \dagger$ ). Therefore, a radical process may not be involved in the reaction pathway.

Based on the above results and previous literatures, ${ }^{9 a, 12}$ two plausible mechanisms for the intramolecular cross dehydrogenative $\mathrm{C}-\mathrm{O}$ coupling are proposed (Scheme 6). In path I, the copper complex $\mathbf{A}$ was generated from 2 and $\mathrm{Cu}(\mathrm{II})$ catalyst. Then, with a ligand assisted concerted metalationdeprotonation (CMD), complex B was formed. The decomplexation of complex $\mathbf{B}$ delivered a six-membered $\mathrm{Cu}(\mathrm{II})$ species C, followed by reductive elimination to afford the cyclized product 1 with concomitant formation of $\mathrm{Cu}(0)$, which is reoxidized to $\mathrm{Cu}$ (II) under air to complete the catalytic cycle. In path II, $\pi$-complex $\mathbf{D}$ was formed via intermediate $\mathbf{A}$, nucleophilic attack of the phenolic $\mathrm{OH}$ results in production of the cyclized intermediate $\mathbf{E}$, which then undergoes $\beta$-hydride elimination to generate the product 1 and $\mathrm{Cu}(0)$.

\section{Conclusions}

We have developed a practical and efficient copper-catalyzed intramolecular cross dehydrogenative $\mathrm{C}-\mathrm{O}$ coupling reaction for the synthesis of coumestans from readily available $2^{\prime}$ hydroxyl-3-arylcoumarins. This protocol delivers natural coumestans and derivatives in moderate to excellent yields. Mild 
and noble metal-free conditions, high efficiency, and good tolerability for phenolic hydroxyl groups make this approach a useful strategy for the construction of coumestan analogues.

\section{Experimental section}

\section{General information}

All reagents used in the synthesis were obtained commercially and used without further purification unless otherwise specified. The reactions were monitored by thin-layer chromatography (TLC) on glass-packed precoated silica gel plates and visualized in an iodine chamber or with a UV lamp (254 $\mathrm{nm})$. The ${ }^{1} \mathrm{H}$ NMR and ${ }^{13} \mathrm{C}$ NMR spectra were recorded using TMS as the internal standard on a Bruker BioSpin GmbH spectrometer at 400, 500, and 100, $125 \mathrm{MHz}$, respectively, and the coupling constants are reported in hertz. The high-resolution mass spectra (HRMS) were obtained using a Shimadzu LCMS-ITTOF mass spectrometer. Flash column chromatography was performed using silica gel (200-300 mesh) purchased from Qingdao Haiyang Chemical Co. Ltd. EPR spectra were recorded on a Bruker A300 spectrometer. X-ray diffraction data were collected at $100 \mathrm{~K}$ on an in-house Oxford Diffraction Xcalibur Nova diffractometer $(\mathrm{Cu}-\mathrm{K} \alpha$ radiation). The data were processed using the program CrysAlis Pro.

\section{General procedure for the synthesis coumestans (1)}

An oven-dried vial was charged with corresponding substrate (2, $1 \mathrm{mmol}), \mathrm{Cu}(\mathrm{OAc})_{2}(0.2 \mathrm{mmol}, 20 \mathrm{~mol} \%), 1,10$-phen $(0.2 \mathrm{mmol}$, $20 \mathrm{~mol} \%)$, DMSO $(3 \mathrm{~mL})$ and $\mathrm{H}_{2} \mathrm{O}(1 \mathrm{~mL})$. The vial was sealed under air and heated to $135{ }^{\circ} \mathrm{C}$ with stirring for 18 hours. After cooling down, the mixture was diluted with $\mathrm{H}_{2} \mathrm{O}(20 \mathrm{~mL})$ and extracted with EtOAc $(20 \mathrm{~mL} \times 3)$. The organic layer was dried, filtered and concentrated to give the crude product which was directly applied to a flash column chromatography using EtOAc/ petroleum ether as the eluent to give the corresponding coumestans (1).

9-Hydroxy-6H-benzofuro[3,2-c]chromen-6-one (1a). ${ }^{\mathbf{1 b}} 196.7 \mathrm{mg}$, $78.0 \%$ yield, white solid. ${ }^{1} \mathrm{H}$ NMR (400 MHz, DMSO- $\left.d_{6}\right) \delta 10.17$ (s, $1 \mathrm{H}), 8.03$ (dd, $J=7.8,1.3 \mathrm{~Hz}, 1 \mathrm{H}), 7.77$ (d, $J=8.4 \mathrm{~Hz}, 1 \mathrm{H}), 7.69$ (ddd, $J=8.7,7.3,1.6 \mathrm{~Hz}, 1 \mathrm{H}), 7.59$ (dd, $J=8.4,0.6 \mathrm{~Hz}, 1 \mathrm{H}), 7.53-$ $7.45(\mathrm{~m}, 1 \mathrm{H}), 7.22$ (d, $J=1.9 \mathrm{~Hz}, 1 \mathrm{H}), 7.00(\mathrm{dd}, J=8.5,2.1 \mathrm{~Hz}, 1 \mathrm{H})$. ${ }^{13} \mathrm{C}$ NMR $\left(100 \mathrm{MHz}, \mathrm{DMSO}-d_{6}\right) \delta 158.3,157.7,157.2,156.4,152.5$, 131.6, 124.9, 121.3, 121.1, 117.0, 114.4, 112.2, 105.4, 98.7. HRMSESI $(\mathrm{m} / \mathrm{z}):[\mathrm{M}+\mathrm{H}]^{+}$calculated for $\mathrm{C}_{15} \mathrm{H}_{9} \mathrm{O}_{4}, 253.0495$, found 253.0494.

6H-Benzofuro[3,2-c]chromen-6-one (1b). ${ }^{3 a} 165.4 \mathrm{mg}, 70.0 \%$ yield, white solid. ${ }^{1} \mathrm{H}$ NMR (400 MHz, DMSO- $\left.d_{6}\right) \delta 8.10$ (dd, $J=$ 7.8, 1.4 Hz, 1H), 8.03-7.97 (m, 1H), $7.92(\mathrm{~d}, J=7.9 \mathrm{~Hz}, 1 \mathrm{H}), 7.75$ (ddd, $J=8.7,7.4,1.6 \mathrm{~Hz}, 1 \mathrm{H}), 7.64-7.50(\mathrm{~m}, 4 \mathrm{H}) .{ }^{13} \mathrm{C}$ NMR $(100$ MHz, DMSO- $\left.d_{6}\right) \delta 160.1,157.6,155.4,153.7,133.0,127.6,125.9$, 125.6, 123.3, 122.4, 121.4, 117.7, 112.8, 112.5, 105.6. HRMS-ESI $(\mathrm{m} / \mathrm{z}):[\mathrm{M}+\mathrm{H}]^{+}$calculated for $\mathrm{C}_{15} \mathrm{H}_{9} \mathrm{O}_{3}, 237.0546$, found 237.0539 .

8-Methoxy-6H-benzofuro[3,2-c] chromen-6-one (1c). ${ }^{3 f} 221.0 \mathrm{mg}$, $83.0 \%$ yield, white solid. ${ }^{1} \mathrm{H}$ NMR (400 MHz, DMSO- $\left.d_{6}\right) \delta 8.11$ (dd, $J$ $=7.8,1.4 \mathrm{~Hz}, 1 \mathrm{H}), 7.86(\mathrm{~d}, J=9.1 \mathrm{~Hz}, 1 \mathrm{H}), 7.80(\mathrm{ddd}, J=8.7,7.3$,
$1.6 \mathrm{~Hz}, 1 \mathrm{H}), 7.67$ (d, $J=7.9 \mathrm{~Hz}, 1 \mathrm{H}), 7.60-7.53(\mathrm{~m}, 1 \mathrm{H}), 7.44(\mathrm{~d}, J=$ $2.6 \mathrm{~Hz}, 1 \mathrm{H}), 7.18$ (dd, $J=9.1,2.7 \mathrm{~Hz}, 1 \mathrm{H}), 3.93(\mathrm{~s}, 3 \mathrm{H}) .{ }^{13} \mathrm{C} \mathrm{NMR}$ $\left(100 \mathrm{MHz}, \mathrm{DMSO}-d_{6}\right) \delta 160.5,157.8,157.7,153.5,150.1,132.9$, $125.5,124.2$, 122.3, 117.7, 115.8, 113.5, 112.5, 105.7, 103.4, 56.2. HRMS-ESI $(m / z):[M+H]^{+}$calculated for $\mathrm{C}_{16} \mathrm{H}_{11} \mathrm{O}_{4}, 267.0652$, found 267.0652 .

8,9-Dimethoxy-6H-benzofuro[3,2-c] chromen-6-one (1d). ${ }^{1 b}$ $210.4 \mathrm{mg}, 71.0 \%$ yield, white solid. ${ }^{1} \mathrm{H}$ NMR $(400 \mathrm{MHz}$, DMSO- $\left.d_{6}\right) \delta 7.95(\mathrm{~d}, J=7.7 \mathrm{~Hz}, 1 \mathrm{H}), 7.71-7.64(\mathrm{~m}, 1 \mathrm{H}), 7.60-$ $7.51(\mathrm{~m}, 2 \mathrm{H}), 7.48(\mathrm{t}, J=7.5 \mathrm{~Hz}, 1 \mathrm{H}), 7.30(\mathrm{~s}, 1 \mathrm{H}), 3.86(\mathrm{~s}, 6 \mathrm{H})$. ${ }^{13} \mathrm{C}$ NMR $\left(100 \mathrm{MHz} \mathrm{CDCl}_{3}\right) \delta 158.8,158.4,152.9,150.3,149.5$, 148.1, 131.1, 124.6, 121.2, 117.4, 115.3, 112.9, 106.3, 102.2, 95.4, 56.5, 56.4. HRMS-ESI $(\mathrm{m} / \mathrm{z}):[\mathrm{M}+\mathrm{H}]^{+}$calculated for $\mathrm{C}_{17} \mathrm{H}_{13} \mathrm{O}_{5}, 297.0758$, found 297.0756 .

8,9,10-Trimethoxy-6H-benzofuro[3,2-c]chromen-6-one (1e). $215.3 \mathrm{mg}, 66.0 \%$ yield, white solid. ${ }^{1} \mathrm{H}$ NMR (400 MHz, DMSO$\left.d_{6}\right) \delta 8.10(\mathrm{dd}, J=7.7,1.4 \mathrm{~Hz}, 1 \mathrm{H}), 7.76-7.68(\mathrm{~m}, 1 \mathrm{H}), 7.59(\mathrm{~d}, J=$ $8.4 \mathrm{~Hz}, 1 \mathrm{H}), 7.50(\mathrm{t}, J=7.6 \mathrm{~Hz}, 1 \mathrm{H}), 7.13(\mathrm{~d}, J=6.5 \mathrm{~Hz}, 1 \mathrm{H}), 4.21$ $(\mathrm{s}, 3 \mathrm{H}), 3.90(\mathrm{~s}, 3 \mathrm{H}), 3.82(\mathrm{~s}, 3 \mathrm{H}) .{ }^{13} \mathrm{C}$ NMR (100 MHz, DMSO- $\left.d_{6}\right)$ $\delta 159.8,157.7,153.2,152.8,141.8,140.6,139.5,132.7,125.5$, 122.2, 119.4, 117.6, 112.5, 105.8, 96.7, 61.5, 56.7. HRMS-ESI $(\mathrm{m} /$ $z):[\mathrm{M}+\mathrm{H}]^{+}$calculated for $\mathrm{C}_{18} \mathrm{H}_{15} \mathrm{O}_{6}, 327.0863$, found 327.0854 .

8,9-Methylenedioxy-6H-benzofuro[3,2-c] chromen-6-one (1f). $109.3 \mathrm{mg}, 39.0 \%$ yield, white solid. ${ }^{1} \mathrm{H}$ NMR (400 MHz, DMSO$\left.d_{6}\right) \delta 8.01(\mathrm{~d}, J=7.5 \mathrm{~Hz}, 1 \mathrm{H}), 7.70(\mathrm{t}, J=7.7 \mathrm{~Hz}, 1 \mathrm{H}), 7.60(\mathrm{~d}, J=$ $10.7 \mathrm{~Hz}, 2 \mathrm{H}), 7.50(\mathrm{t}, J=7.5 \mathrm{~Hz}, 1 \mathrm{H}), 7.33(\mathrm{~s}, 1 \mathrm{H}), 6.18(\mathrm{~s}, 2 \mathrm{H})$. ${ }^{13} \mathrm{C} \mathrm{NMR}\left(100 \mathrm{MHz}, \mathrm{CDCl}_{3}\right) \delta 159.2,158.3,152.9,151.0,147.9$, $146.3,131.2,124.7,121.3,117.5,116.9,112.9$, 106.5, 102.1, 100.3, 94.1. HRMS-ESI $(\mathrm{m} / \mathrm{z}):[\mathrm{M}+\mathrm{H}]^{+}$calculated for $\mathrm{C}_{16} \mathrm{H}_{9} \mathrm{O}_{5}$, 281.0444 , found 281.0444 .

11-Hydroxy-8H-benzo[f]benzofuro[3,2-c]chromen-8-one (1g). $211.6 \mathrm{mg}, 70.0 \%$ yield, white solid. ${ }^{1} \mathrm{H}$ NMR (400 MHz, DMSO$\left.d_{6}\right) \delta 10.22(\mathrm{~s}, 1 \mathrm{H}), 9.12(\mathrm{~d}, J=8.4 \mathrm{~Hz}, 1 \mathrm{H}), 8.22(\mathrm{~d}, J=9.0 \mathrm{~Hz}$, $1 \mathrm{H}), 8.12(\mathrm{~d}, J=7.9 \mathrm{~Hz}, 1 \mathrm{H}), 7.85(\mathrm{dd}, J=15.4,8.0 \mathrm{~Hz}, 2 \mathrm{H}), 7.70$ (dd, $J=15.3,8.2 \mathrm{~Hz}, 2 \mathrm{H}), 7.35(\mathrm{~s}, 1 \mathrm{H}), 7.04(\mathrm{~d}, J=8.3 \mathrm{~Hz}, 1 \mathrm{H})$. ${ }^{13} \mathrm{C}$ NMR $\left(100 \mathrm{MHz}, \mathrm{DMSO}-d_{6}\right) \delta 160.1,158.2,157.7,156.9$, $153.1,133.1,130.5,129.5,129.4$, 127.1, 126.9, 125.5, 121.6, 117.7, 115.1, 114.3, 107.1, 106.2, 99.2. HRMS-ESI $(\mathrm{m} / \mathrm{z}):[\mathrm{M}+\mathrm{H}]^{+}$ calculated for $\mathrm{C}_{19} \mathrm{H}_{11} \mathrm{O}_{4}, 303.0652$, found 303.0645.

3-Hydroxy-6H-benzofuro[3,2-c]chromen-6-one (1h). $204.3 \mathrm{mg}$, 81.0\% yield, white solid. ${ }^{1} \mathrm{H}$ NMR (400 MHz, DMSO- $\left.d_{6}\right) \delta 10.78(\mathrm{~s}$, $1 \mathrm{H}), 7.88-7.79(\mathrm{~m}, 2 \mathrm{H}), 7.78-7.71(\mathrm{~m}, 1 \mathrm{H}), 7.49-7.35(\mathrm{~m}, 2 \mathrm{H})$, 6.94-6.81 (m, 2H). ${ }^{13} \mathrm{C}$ NMR (100 MHz, DMSO- $\left.d_{6}\right) \delta 162.4,161.1$, 157.9, 155.7, 154.9, 126.7, 125.7, 123.7, 123.6, 120.8, 114.4, 112.4, 104.3, 103.5, 102.2, 40.6, 40.4, 40.2, 39.9, 39.7, 39.5, 39.3. HRMSESI $(\mathrm{m} / \mathrm{z}):[\mathrm{M}+\mathrm{H}]^{+}$calculated for $\mathrm{C}_{15} \mathrm{H}_{9} \mathrm{O}_{4}, 253.0495$, found 253.0493.

3-Hydroxy-6H-benzofuro[3,2-c]chromen-6-one (1i). $163.7 \mathrm{mg}$, $58.0 \%$ yield, white solid. ${ }^{1} \mathrm{H}$ NMR (400 MHz, DMSO- $\left.d_{6}\right) \delta 10.86$ $(\mathrm{s}, 1 \mathrm{H}), 7.92(\mathrm{~d}, J=8.6 \mathrm{~Hz}, 1 \mathrm{H}), 7.77(\mathrm{~d}, J=9.0 \mathrm{~Hz}, 1 \mathrm{H}), 7.37$ (d, $J$ $=2.6 \mathrm{~Hz}, 1 \mathrm{H}), 7.09(\mathrm{dd}, J=9.0,2.7 \mathrm{~Hz}, 1 \mathrm{H}), 7.04-6.91(\mathrm{~m}, 2 \mathrm{H})$, $3.90(\mathrm{~s}, 3 \mathrm{H}) .{ }^{13} \mathrm{C}$ NMR $\left(100 \mathrm{MHz}, \mathrm{DMSO}-d_{6}\right) \delta 162.3,161.6,157.9$, $157.6,155.6,149.6,124.5,123.7,114.7,114.3$, 113.1, 104.4, 103.6, 103.3, 102.4, 56.2. HRMS-ESI $(\mathrm{m} / \mathrm{z}):[\mathrm{M}+\mathrm{H}]^{+}$calculated for $\mathrm{C}_{16} \mathrm{H}_{11} \mathrm{O}_{5}, 283.0601$, found 283.0595.

3-Hydroxy-8,9,10-trimethoxy-6H-benzofuro[3,2-c]chromen-6one (1j). $181.4 \mathrm{mg}, 53 \%$ yield, white solid. ${ }^{1} \mathrm{H}$ NMR $(400 \mathrm{MHz}$, 
DMSO- $\left.d_{6}\right) \delta 10.77(\mathrm{~s}, 1 \mathrm{H}), 7.95(\mathrm{~d}, J=8.5 \mathrm{~Hz}, 1 \mathrm{H}), 7.13(\mathrm{~s}, 1 \mathrm{H})$, $6.95(\mathrm{dd}, J=8.5,2.2 \mathrm{~Hz}, 1 \mathrm{H}), 6.93$ (d, $J=2.0 \mathrm{~Hz}, 1 \mathrm{H}), 4.19$ (s, $3 \mathrm{H}), 3.90(\mathrm{~s}, 3 \mathrm{H}), 3.81(\mathrm{~s}, 3 \mathrm{H}) .{ }^{13} \mathrm{C}$ NMR (100 MHz, DMSO- $\left.d_{6}\right)$ $\delta 162.1,160.9,158.0,155.4,152.6,141.2,139.9,139.5,123.6$, $119.7,114.3,104.4,103.5,102.5,96.5,61.5,61.5$, 56.7. HRMSESI $(\mathrm{m} / \mathrm{z}):[\mathrm{M}+\mathrm{H}]^{+}$calculated for $\mathrm{C}_{18} \mathrm{H}_{15} \mathrm{O}_{7}, 343.0812$, found 343.0803 .

2-Methyl-6H-benzofuro[3,2-c] chromen-6-one (1k). ${ }^{3 b} 145.1 \mathrm{mg}$, $58.0 \%$ yield, white solid. ${ }^{1} \mathrm{H}$ NMR $\left(400 \mathrm{MHz}\right.$, DMSO- $\left.d_{6}\right) \delta 7.96(\mathrm{~d}, J$ $=7.3 \mathrm{~Hz}, 1 \mathrm{H}), 7.90-7.79(\mathrm{~m}, 2 \mathrm{H}), 7.59-7.44(\mathrm{~m}, 4 \mathrm{H}), 2.43(\mathrm{~s}, 3 \mathrm{H})$. ${ }^{13} \mathrm{C}$ NMR $\left(100 \mathrm{MHz}, \mathrm{CDCl}_{3}\right) \delta 160.0,158.2,155.5,151.9,134.5$, 133.0, 126.6, 125.1, 123.6, 121.8, 121.5, 117.2, 112.3, 111.7, 105.8, 20.9. HRMS-ESI $(\mathrm{m} / \mathrm{z}):[\mathrm{M}+\mathrm{H}]^{+}$calculated for $\mathrm{C}_{16} \mathrm{H}_{11} \mathrm{O}_{3}, 251.0703$, found 251.0701 .

3-Methoxy-6H-benzofuro[3,2-c]chromen-6-one (11) ${ }^{14} 202.3 \mathrm{mg}$, $76.0 \%$ yield, white solid. ${ }^{1} \mathrm{H}$ NMR (400 MHz, DMSO- $\left.d_{6}\right) \delta 8.00(\mathrm{~d}, J$ $=8.7 \mathrm{~Hz}, 1 \mathrm{H}), 7.97-7.91(\mathrm{~m}, 1 \mathrm{H}), 7.87(\mathrm{dd}, J=6.9,1.7 \mathrm{~Hz}, 1 \mathrm{H})$, $7.57-7.46(\mathrm{~m}, 2 \mathrm{H}), 7.22(\mathrm{~d}, J=2.3 \mathrm{~Hz}, 1 \mathrm{H}), 7.11(\mathrm{dd}, J=8.8,2.4 \mathrm{~Hz}$, $1 \mathrm{H}), 3.91(\mathrm{~s}, 3 \mathrm{H}) .{ }^{13} \mathrm{C} \mathrm{NMR}\left(100 \mathrm{MHz}, \mathrm{CDCl}_{3}\right) \delta 168.2,165.5,162.6$, 160.4, 159.9, 131.7, 130.6, 128.3, 125.7, 118.5, 117.3, 110.3, 107.7, 106.9, 61.3. HRMS-ESI $(\mathrm{m} / \mathrm{z}):[\mathrm{M}+\mathrm{H}]^{+}$calculated for $\mathrm{C}_{16} \mathrm{H}_{11} \mathrm{O}_{4}$, 267.0652 , found 267.0650 .

2-Chloro-6H-benzofuro[3,2-c]chromen-6-one (1m). ${ }^{3 m} 108.3 \mathrm{mg}$, $40.0 \%$ yield, white solid. ${ }^{1} \mathrm{H}$ NMR $\left(400 \mathrm{MHz} \mathrm{CDCl}_{3}\right) \delta 8.20-8.11(\mathrm{~m}$, $1 \mathrm{H}), 8.02(\mathrm{~d}, J=2.3 \mathrm{~Hz}, 1 \mathrm{H}), 7.69(\mathrm{~d}, J=8.1 \mathrm{~Hz}, 1 \mathrm{H}), 7.58-7.43(\mathrm{~m}$, $4 \mathrm{H}) .{ }^{13} \mathrm{C} \mathrm{NMR}\left(100 \mathrm{MHz}, \mathrm{CDCl}_{3}\right) \delta 158.6,157.4,155.7,151.9,131.9$, 130.3, 127.3, 125.5, 123.2, 122.0, 121.4, 118.9, 113.7, 111.9, 106.6. HRMS-ESI $(\mathrm{m} / \mathrm{z}):[\mathrm{M}+\mathrm{H}]^{+}$calculated for $\mathrm{C}_{15} \mathrm{H}_{8} \mathrm{ClO}_{3}, 271.0156$, found 271.0156 .

9-Hydroxy-3-methoxy-6H-benzofuro[3,2-c]chromen-6-one (1n). ${ }^{13} 223.0 \mathrm{mg}, 79.0 \%$ yield, white solid. ${ }^{1} \mathrm{H}$ NMR $(400 \mathrm{MHz}$, DMSO- $\left.d_{6}\right) \delta 10.07(\mathrm{~s}, 1 \mathrm{H}), 7.95(\mathrm{~d}, J=8.7 \mathrm{~Hz}, 1 \mathrm{H}), 7.72(\mathrm{~d}, J=$ $8.4 \mathrm{~Hz}, 1 \mathrm{H}), 7.32-7.14(\mathrm{~m}, 2 \mathrm{H}), 7.10(\mathrm{~d}, J=8.7 \mathrm{~Hz}, 1 \mathrm{H}), 6.97$ (d, $J$ $=8.4 \mathrm{~Hz}, 1 \mathrm{H}), 3.90(\mathrm{~s}, 3 \mathrm{H}) .{ }^{13} \mathrm{C}$ NMR $\left(100 \mathrm{MHz}\right.$, DMSO- $\left.d_{6}\right)$ $\delta 162.8,159.6,157.9,157.7,156.6,155.0,122.9,121.2,114.9$, 114.6, 113.5, 105.9, 103.3, 102.1, 99.2, 56.5. HRMS-ESI $(\mathrm{m} / \mathrm{z})$ : [M $+\mathrm{H}]^{+}$calculated for $\mathrm{C}_{16} \mathrm{H}_{11} \mathrm{O}_{5}, 283.0601$, found 283.0598 .

3,8,9-Trimethoxy-6H-benzofuro[3,2-c] chromen-6-one (10). ${ }^{3 d}$ $225.1 \mathrm{mg}, 69.0 \%$ yield, white solid. ${ }^{1} \mathrm{H}$ NMR (400 MHz, DMSO$\left.d_{6}\right) \delta 7.93(\mathrm{~d}, J=8.4 \mathrm{~Hz}, 1 \mathrm{H}), 7.58(\mathrm{~s}, 1 \mathrm{H}), 7.35(\mathrm{~s}, 1 \mathrm{H}), 7.21(\mathrm{~s}$, $1 \mathrm{H}), 7.11(\mathrm{~d}, J=8.1 \mathrm{~Hz}, 1 \mathrm{H}), 3.89$ (d, $J=10.3 \mathrm{~Hz}, 9 \mathrm{H}) .{ }^{13} \mathrm{C} \mathrm{NMR}$ $\left(100 \mathrm{MHz}, \mathrm{CDCl}_{3}\right) \delta 162.5,159.8,158.8,154.9,150.0,149.1$, 148.0, 122.3, 115.6, 113.0, 106.3, 103.9, 102.3, 101.5, 95.6, 56.6, 56.4, 55.8. HRMS-ESI $(\mathrm{m} / \mathrm{z}):[\mathrm{M}+\mathrm{H}]^{+}$calculated for $\mathrm{C}_{18} \mathrm{H}_{15} \mathrm{O}_{6}$, 327.0863 , found 327.0861 .

3,8,9,10-Tetramethoxy- $6 \boldsymbol{H}$-benzofuro[3,2-c] chromen-6-one (1p). $238.7 \mathrm{mg}, 67.0 \%$ yield, white solid. ${ }^{1} \mathrm{H}$ NMR $(400 \mathrm{MHz}$, DMSO- $\left.d_{6}\right) \delta 7.90(\mathrm{~d}, J=8.7 \mathrm{~Hz}, 1 \mathrm{H}), 7.09$ (s, 1H), $7.02(\mathrm{~d}, J=$ $10.0 \mathrm{~Hz}, 2 \mathrm{H}), 4.19$ (s, 3H), 3.88 (s, 3H), 3.86 (s, 3H), 3.81 (s, 3H). ${ }^{13} \mathrm{C}$ NMR $\left(100 \mathrm{MHz}, \mathrm{DMSO}-d_{6}\right) \delta 163.1,160.3,157.8,155.1$, $152.6,141.3,140.0,139.4,123.2,119.5,113.5,105.5,103.0$, 101.9, 96.4, 61.5, 61.4, 56.6, 56.5. HRMS-ESI $(\mathrm{m} / \mathrm{z}):[\mathrm{M}+\mathrm{H}]^{+}$ calculated for $\mathrm{C}_{19} \mathrm{H}_{17} \mathrm{O}_{7}, 357.0969$, found 357.0964 .

3,8-Dimethoxy-6H-benzofuro[3,2-c] chromen-6-one (1q). $228.1 \mathrm{mg}, 77.0 \%$ yield, white solid. ${ }^{1} \mathrm{H}$ NMR $(400 \mathrm{MHz}$, DMSO- $\left.d_{6}\right) \delta 7.99(\mathrm{~d}, J=8.7 \mathrm{~Hz}, 1 \mathrm{H}), 7.80(\mathrm{~d}, J=9.0 \mathrm{~Hz}, 1 \mathrm{H})$, $7.39(\mathrm{~s}, 1 \mathrm{H}), 7.23(\mathrm{~s}, 1 \mathrm{H}), 7.12(\mathrm{dd}, J=12.5,5.6 \mathrm{~Hz}, 2 \mathrm{H}), 3.96$ (s, 3H), $3.91(\mathrm{~s}, 3 \mathrm{H}) \cdot{ }^{13} \mathrm{C}$ NMR $\left(100 \mathrm{MHz}, \mathrm{CDCl}_{3}\right) \delta$ 162.9, 161.2, 158.6, 157.6, 155.5, 149.9, 124.4, 122.8, 115.2, 113.1, 112.1, 106.1, 103.4, 101.4, 100.0, 56.0, 55.8. HRMS-ESI $(\mathrm{m} / \mathrm{z})$ : $[\mathrm{M}+\mathrm{H}]^{+}$calculated for $\mathrm{C}_{17} \mathrm{H}_{13} \mathrm{O}_{5}, 297.0758$, found 297.0756 .

1,3,8,9-Tetramethoxy- $6 \mathrm{H}$-benzofuro[3,2-c]chromen-6-one (1r). ${ }^{3 d} 131.8 \mathrm{mg}, 37.0 \%$ yield, white solid. ${ }^{1} \mathrm{H}$ NMR $(400 \mathrm{MHz}$, DMSO- $\left.d_{6}\right) \delta 7.51(\mathrm{~s}, 1 \mathrm{H}), 7.31(\mathrm{~s}, 1 \mathrm{H}), 6.76(\mathrm{~s}, 1 \mathrm{H}), 6.64(\mathrm{~s}, 1 \mathrm{H})$, $4.00(\mathrm{~s}, 3 \mathrm{H}), 3.88(\mathrm{~d}, J=6.3 \mathrm{~Hz}, 9 \mathrm{H}) .{ }^{13} \mathrm{C}$ NMR (100 MHz, DMSO$\left.d_{6}\right) \delta 162.6,160.1,155.3,145.7,143.2,143.1,142.8,142.0,129.8$, 122.4, 117.8, 113.3, 112.9, 110.2, 100.8, 61.3, 60.9, 56.8, 56.4. HRMS-ESI $(\mathrm{m} / \mathrm{z}):[\mathrm{M}+\mathrm{H}]^{+}$calculated for $\mathrm{C}_{19} \mathrm{H}_{17} \mathrm{O}_{7}, 357.0969$, found 357.0965.

3,9-Dihydroxy-6H-benzofuro[3,2-c]chromen-6-one (coumestrol, $1 \mathrm{~s}){ }^{5 c} 1 \mathrm{~s}$ was obtained from $2 \mathrm{~s}$ following general procedure. $128.7 \mathrm{mg}, 48.0 \%$ yield, white solid. Mp 361-364 ${ }^{\circ} \mathrm{C} .{ }^{1} \mathrm{H}$ NMR $\left(400 \mathrm{MHz}, \mathrm{DMSO}-d_{6}\right) \delta 10.70(\mathrm{~s}, 1 \mathrm{H}), 10.04(\mathrm{~s}, 1 \mathrm{H}), 7.87(\mathrm{~d}, J=$ $8.5 \mathrm{~Hz}, 1 \mathrm{H}), 7.70$ (d, $J=8.4 \mathrm{~Hz}, 1 \mathrm{H}), 7.17$ (d, $J=1.7 \mathrm{~Hz}, 1 \mathrm{H})$, 7.01-6.86 (m, 3H). ${ }^{13} \mathrm{C}$ NMR (100 MHz, DMSO- $\left.d_{6}\right) \delta 161.8,159.9$, $158.1,157.5$, 156.4, 155.1, 123.2, 121.1, 115.1, 114.5, 114.3, 104.6, 103.5, 102.5, 99.2. HRMS-ESI: $m / z[\mathrm{M}+\mathrm{H}]^{+}$calculated for $\mathrm{C}_{15} \mathrm{H}_{9} \mathrm{O}_{5}$ 269.0444, found 269.0446.

3-Hydroxy-9-methoxy-6H-benzofuro[3,2-c] chromen-6-one(9methoxy-coumestrol, 1t). ${ }^{3 d}$ 1t was obtained from $2 \mathrm{t}$ following general procedure. $177.8 \mathrm{mg}, 63.0 \%$ yield, white solid. ${ }^{1} \mathrm{H}$ NMR $\left(400 \mathrm{MHz}, \mathrm{DMSO}-d_{6}\right) \delta 10.76(\mathrm{~s}, 1 \mathrm{H}), 7.87(\mathrm{~d}, J=8.6 \mathrm{~Hz}, 1 \mathrm{H}), 7.79$ $(\mathrm{d}, J=8.6 \mathrm{~Hz}, 1 \mathrm{H}), 7.50(\mathrm{~d}, J=2.1 \mathrm{~Hz}, 1 \mathrm{H}), 7.10(\mathrm{dd}, J=8.6$, $2.2 \mathrm{~Hz}, 1 \mathrm{H}), 7.02-6.88$ (m, 2H), 3.87 (s, 3H). ${ }^{13} \mathrm{C}$ NMR (100 MHz, DMSO- $\left.d_{6}\right) \delta 161.9,160.5,159.3,158.0,156.4,155.3,123.3,121.0$, 116.4 114.3, 113.9, 104.6, 103.6, 102.4, 97.8, 56.4. HRMS-ESI $(\mathrm{m} /$ $z):[\mathrm{M}+\mathrm{H}]^{+}$calculated for $\mathrm{C}_{16} \mathrm{H}_{11} \mathrm{O}_{5}, 283.0601$, found 283.0602 .

3-Hydroxy-8,9-dimethoxy-6H-benzofuro[3,2-c]chromen-6one(8,9-dimethoxy-coumestrol, $1 \mathbf{u}) \cdot{ }^{3 a} \mathbf{1 u}$ was obtained from $2 \mathbf{u}$ following general procedure. $190.5 \mathrm{mg}, 61.0 \%$ yield, white solid. ${ }^{1} \mathrm{H}$ NMR (400 MHz, DMSO- $\left.d_{6}\right) \delta 10.70(\mathrm{~s}, 1 \mathrm{H}), 7.84(\mathrm{~d}, J=8.5 \mathrm{~Hz}$, $1 \mathrm{H}), 7.55(\mathrm{~s}, 1 \mathrm{H}), 7.33(\mathrm{~s}, 1 \mathrm{H}), 7.05-6.83(\mathrm{~m}, 2 \mathrm{H}), 3.87(\mathrm{~s}, 6 \mathrm{H}) .{ }^{13} \mathrm{C}$ NMR (100 MHz, DMSO- $\left.d_{6}\right) \delta$ 161.6, 159.9, 158.1, 155.0, 149.8, 149.3, 148.2, 123.1, 115.1, 114.3, 104.7, 103.5, 102.7, 101.9, 97.2, 56.6, 56.4. HRMS-ESI $(\mathrm{m} / \mathrm{z}):[\mathrm{M}+\mathrm{H}]^{+}$calculated for $\mathrm{C}_{17} \mathrm{H}_{13} \mathrm{O}_{6}$, 313.0707, found 313.0704.

3-Hydroxy-8,9-methylenedioxy-6H-benzofuro[3,2-c]chromen6-one (medicagol, 1v). ${ }^{2 g}$ 1v was obtained from $2 \mathbf{v}$ following general procedure.106.6 mg, 36.0\% yield, white solid. ${ }^{1} \mathrm{H}$ NMR $\left(400 \mathrm{MHz}, \mathrm{DMSO}-d_{6}\right) \delta 10.73(\mathrm{~s}, 1 \mathrm{H}), 7.83(\mathrm{dd}, J=8.5,2.8 \mathrm{~Hz}$, $1 \mathrm{H}), 7.56(\mathrm{~d}, J=3.3 \mathrm{~Hz}, 1 \mathrm{H}), 7.28(\mathrm{~d}, J=3.5 \mathrm{~Hz}, 1 \mathrm{H}), 6.92(\mathrm{dd}, J=$ 11.0, $5.1 \mathrm{~Hz}, 2 \mathrm{H}), 6.16(\mathrm{~s}, 2 \mathrm{H}) .{ }^{13} \mathrm{C}$ NMR (100 MHz, DMSO- $\left.d_{6}\right)$ $\delta 161.2,159.8,157.5,154.5,149.8,146.9,145.8,122.6,116.3$, 113.8, 104.1, 103.0, 102.4, 102.1, 98.7, 94.7. HRMS-ESI $(\mathrm{m} / \mathrm{z})$ : [M $+\mathrm{H}]^{+}$calculated for $\mathrm{C}_{16} \mathrm{H}_{9} \mathrm{O}_{6}, 297.0394$, found 297.0391 .

3-Methoxy-8,9-methylenedioxy- $6 H$-benzofuro[3,2-c]chromen6-one (flemichapparin $\mathrm{C}, \mathbf{1 w}) \cdot{ }^{3 a} \mathbf{1 w}$ was obtained from $2 \mathrm{w}$ following general procedure. $152.0 \mathrm{mg}, 49.0 \%$ yield, pale yellow solid. Mp 270-272 ${ }^{\circ} \mathrm{C} .{ }^{1} \mathrm{H}$ NMR $\left(400 \mathrm{MHz}, \mathrm{DMSO}-d_{6}\right) \delta 7.92(\mathrm{~d}, J=$ $8.5 \mathrm{~Hz}, 1 \mathrm{H}), 7.58$ (s, 1H), $7.30(\mathrm{~s}, 1 \mathrm{H}), 7.20$ (s, 1H), 7.09 (d, $J=$ $8.2 \mathrm{~Hz}, 1 \mathrm{H}), 6.16$ (s, 2H), 3.90 (s, 3H). ${ }^{13} \mathrm{C}$ NMR (100 MHz, DMSO$\left.d_{6}\right) \delta 163.2,160.6,156.1,155.9,150.5,147.9,140.0,137.7,119.5$, 114.4, 110.4, 103.7, 101.4, 98.3, 97.7, 92.5, 56.15. HRMS-ESI $(\mathrm{m} / \mathrm{z})$ : $[\mathrm{M}+\mathrm{H}]^{+}$calculated for $\mathrm{C}_{17} \mathrm{H}_{11} \mathrm{O}_{6}, 311.0550$, found 311.0550 . 
8,9,10-Trimethoxy-3-((methylthio)methoxy)-6H-benzofuro[3,2c]chromen-6-one (1jj). $124.7 \mathrm{mg}, 31.0 \%$ yield, pale yellow solid. ${ }^{1} \mathrm{H}$ NMR (400 MHz, DMSO- $\left.d_{6}\right) \delta 8.03(\mathrm{~d}, J=8.7 \mathrm{~Hz}, 1 \mathrm{H}), 7.29(\mathrm{~d}, J$ $=2.3 \mathrm{~Hz}, 1 \mathrm{H}), 7.16(\mathrm{dd}, J=8.7,2.3 \mathrm{~Hz}, 1 \mathrm{H}), 7.13(\mathrm{~s}, 1 \mathrm{H}), 5.46(\mathrm{~s}$, 2H), $4.20(\mathrm{~s}, 3 \mathrm{H}), 3.90(\mathrm{~s}, 3 \mathrm{H}), 3.82(\mathrm{~s}, 3 \mathrm{H}), 2.23(\mathrm{~s}, 3 \mathrm{H}) .{ }^{13} \mathrm{C} \mathrm{NMR}$ $\left(100 \mathrm{MHz}, \mathrm{DMSO}-d_{6}\right) \delta 160.6,160.4,157.9,154.9,152.7,141.4$, 140.2, 139.5, 123.3, 119.6, 114.9, 106.3, 104.2, 103.5, 96.6, 72.9, 61.5 , 56.7, 14.4. HRMS-ESI $(\mathrm{m} / \mathrm{z}):[\mathrm{M}+\mathrm{H}]^{+}$calculated for $\mathrm{C}_{20} \mathrm{H}_{19} \mathrm{O}_{7} \mathrm{~S}, 403.0846$, found 403.0853 .

\section{Conflicts of interest}

There are no conflicts to declare.

\section{Acknowledgements}

This project was supported by the National Key Research and Development Project of China (2016YFA0602900), the National Natural Science Foundation of China (21272280), the Key Project of Guangdong Natural Science Foundation (2016A030311033), the Science and Technology Programme of Guangzhou City (201505041557046), and the Innovative Scientific Research Team Introducing Project of Zhongshan City (2015-224). M. K. Li is an intern student at Shanghai Starriver Bilingual School accredited to SYSU. We are thankful to Prof. Albert S. C. Chan at SYSU for guidance and help.

\section{Notes and references}

1 (a) E. M. Bickoff, R. L. Lyman, A. L. Livingston and A. N. Booth, J. Am. Chem. Soc., 1958, 80, 3969-3971; (b) G.-L. Xi and Z.-Q. Liu, J. Agric. Food Chem., 2014, 62, 56365642; (c) V. A. Tuskaev, Pharm. Chem. J., 2013, 47, 1-11; (d) W. Zhang, S. Lun, S. Wang, X. Jiang, F. Yang, J. Tang, A. L. Manson, A. M. Earl, H. Gunosewoyo, W. R. Bishai and L.-F. Yu, J. Med. Chem., 2018, 61, 791-803.

2 (a) Y. Xia, J. Chen, Y. Cao, C. Xu, R. Li, Y. Pan and X. Chen, Eur. J. Pharmacol., 2013, 714, 105-111; (b) S. Lim, H.-J. Jang, E. H. Park, J. K. Kim, J.-M. Kim, E.-K. Kim, K. Yea, Y.-H. Kim, W. Lee-Kwon, S. H. Ryu and P.-G. Suh, J. Cell. Biochem., 2012, 113, 3436-3445; (c) L. Li, X. Deng, L. Zhang, P. Shu and M. Qin, Fitoterapia, 2011, 82, 615619; (d) Y. Chen, X. Wei, H. Xie and H. Deng, J. Nat. Prod., 2008, 71, 929-932; (e) M.-Y. Xu and Y.-S. Kim, Food Chem. Toxicol., 2014, 74, 311-319; ( $f$ ) T. Nehybova, J. Smarda, L. Daniel, J. Brezovsky and P. Benes, J. Steroid Biochem. Mol. Biol., 2015, 152, 76-83; (g) A. J. M. DaSilva, P. A. Melo, N. M. V. Silva, F. V. Brito, C. D. Buarque, D. V. de Souza, V. P. Rodrigues, E. S. C. Pocas, F. Noel, E. X. Albuquerque and P. R. R. Costa, Bioorg. Med. Chem. Lett., 2001, 11, 283286.

3 (a) K. Mackey, L. M. Pardo, A. M. Prendergast, M.-T. Nolan, L. M. Bateman and G. P. McGlacken, Org. Lett., 2016, 18, 2540-2543; (b) K. Neog, A. Borah and P. Gogoi, J. Org. Chem., 2016, 81, 11971-11977; (c) A. R. Kapdi, A. Karbelkar, M. Naik, S. Pednekar, C. Fischer, C. Schulzkec and M. Tromp, RSC Adv., 2013, 3, 20905-20912; (d) L. Tang,
Y. Pang, Q. Yan, L. Shi, J. Huang, Y. Du and K. Zhao, J. Org. Chem., 2011, 76, 2744-2752; (e) U. A. Kshirsagar, R. Parnes, H. Goldshtein, R. Ofir, R. Zarivach and D. Pappo, Chem.-Eur. J., 2013, 19, 13575-13583; (f) J. Liu, Y. Liu, W. Du, Y. Dong, J. Liu and M. Wang, J. Org. Chem., 2013, 78, 7293-7297; (g) J. Zhang, J. Qiu, C. Xiao, L. Yu, F. Yang and J. Tang, Eur. J. Org. Chem., 2016, 3380-3385; (h) T. Yao, D. Yue and R. C. Larock, J. Org. Chem., 2005, 70, 9985-9989; (i) M. T. Nolan, L. M. Pardo, A. M. Prendergast and G. P. McGlacken, J. Org. Chem., 2015, 80, 10904-10913; (j) C. Cheng, W. Chen, B. Xu and M.-H. Xu, Org. Chem. Front., 2016, 3, 1111-1115; (k) K. Kurosawa and K. Nogami, Bull. Chem. Soc. Jpn., 1976, 49, 1955-1957; (l) R. S. Mali and S. G. Tilve, Synth. Commun., 1990, 20, 1781-1791; (m) M. Naik, V. P. Kamat and S. G. Tilve, Tetrahedron, 2017, 73, 5528-5536; (n) C.-F. Chang, L.-Y. Yang, S.-W. Chang, Y.-T. Fang and Y.-J. Lee, Tetrahedron, 2008, 64, 3661-3666; (o) D. H. Gong, C. Z. Li and C. Y. Yuan, Chin. J. Chem., 2001, 19, 522-527; (p) S. B. Pandit and S. Y. Gadre, Synth. Commun., 1988, 18, 157-166.

4 (a) C. C. Li, Z. X. Xie, Y. D. Zhang, J. H. Chen and Z. Yang, J. Org. Chem., 2003, 68, 8500-8504; (b) T. Yao, D. Yue and R. C. Larock, J. Org. Chem., 2005, 70, 9985-9989; (c) K. Hiroya, N. Suzuki, A. Yasuhara, Y. Egawa, A. Kasano and T. Sakamoto, J. Chem. Soc., Perkin Trans. 1, 2000, 4339-4346. 5 (a) P. Pahari and J. Rohr, J. Org. Chem., 2009, 74, 2750-2754; (b) G. A. Kraus and N. Zhang, J. Org. Chem., 2000, 65, 56445646; (c) N. Al-Maharik and N. P. Botting, Tetrahedron, 2004, 60, 1637-1642.

6 (a) Z. Grujic, I. Tabakovic and H. Trkovnik, Tetrahedron Lett., 1976, 17, 4823-4824; (b) I. Tabakovic, Z. Grujic and Z. Bejtovic, J. Heterocycl. Chem., 1983, 20, 635; (c) G. Pandey, C. Muralikrrshna and U. T. Bhalerao, Tetrahedron, 1989, 45, 6867-6874; (d) S. Angeleska, P. Kefalas and A. Detsi, Tetrahedron Lett., 2013, 54, 23252328.

7 For recent reviews and selected examples, see: (a) I. P. Beletskaya and A. V. Cheprakov, Coord. Chem. Rev., 2004, 248, 2337-2364; (b) K. Nejati, S. Ahmadi, M. Nikpassand, P. D. K. Nezhad and E. Vessally, RSC Adv., 2018, 8, 19125-19143; (c) C. Sambiagio, S. P. Marsden, A. J. Blacker and P. C. McGowan, Chem. Soc. Rev., 2014, 43, 3525-3550; (d) G. Evano, N. Blanchard and M. Toumi, Chem. Rev., 2008, 108, 3054-3131; (e) S. Bhunia, G. G. Pawar, S. V. Kumar, Y. Jiang and D. Ma, Angew. Chem., Int. Ed., 2017, 56, 16136-16179; (f) G. Evano, J. Wang and A. Nitelet, Org. Chem. Front., 2017, 4, 24802499; (g) S. Enthaler and A. Company, Chem. Soc. Rev., 2011, 40, 4912-4924; (h) A. Shao, J. Zhan, N. Li, C.-W. Chiang and A. Lei, J. Org. Chem., 2018, 83, 35823589; (i) H. Yi, L. Niu, C. Song, Y. Li, B. Dou, A. K. Singh and A. Lei, Angew. Chem., Int. Ed., 2017, 56, 1120-1124; (j) R. Skouta and C.-J. Li, Angew. Chem., Int. Ed., 2007, 46, 1117-1119; (k) M.-O. Simon, S. A. Girard and C.-J. Li, Angew. Chem., Int. Ed., 2012, 51, 7537-7540.

8 (a) S. Ueda and H. Nagasawa, J. Org. Chem., 2009, 74, 42724277; (b) J. Zhao, Y. Wang, Y. He, L. Liu and Q. Zhu, Org. 
Lett., 2012, 14, 1078-1081; (c) T. Xiong, Y. Li, X. Bi, Y. Lv and Q. Zhang, Angew. Chem., Int. Ed., 2011, 50, 7140-7143; (d) A. Modak, U. Dutta, R. Kancherla, S. Maity, M. Bhadra, S. M. Mobin and D. Maiti, Org. Lett., 2014, 16, 2602-2605; (e) S. Guin, T. Ghosh, S. K. Rout, A. Banerijee and B. K. Patel, Org. Lett., 2011, 13, 5976-5979.

9 (a) T. Xu, E. Zhang, D. Wang, Y. Wang and Y. Zou, J. Org. Chem., 2015, 80, 4313-4324; (b) J. Sheng, T. Xu, E. Zhang, X. Zhang, W. Wei and Y. Zou, J. Nat. Prod., 2016, 79, 27492753; (c) X. Huang, J. Liu, J. Sheng, X. Song, Z. Du, M. Li, X. Zhang and Y. Zou, Green Chem., 2018, 20, 804-808; (d) H. Sun, C. Xiao, Y. Cai, Y. Chen, W. Wei, X. Liu, Z.-L. Lv and Y. Zou, Chem. Pharm. Bull., 2010, 58, 1492-1496; (e) Y. Zou, Q. Huang, T. Huang, Q. Ni, E. Zhang, T. Xu, M. Yuan and J. Li, Org. Biomol. Chem., 2013, 11, 6967-6974.
10 Crystallographic data of $1 e\left(\mathrm{C}_{18} \mathrm{H}_{14} \mathrm{O}_{6}\right)$ have been deposited at the Cambridge Crystallographic Data Centre (CCDC) with the reference number 1552229.

11 L. A. Oparina, O. V. Vysotskaya, N. A. Kolyvanov, N. K. Gusarova and B. A. Trofimov, Russ. J. Org. Chem., 2014, 50, 1199-1200.

12 (a) X. Wang, Y. Jin, Y. Zhao, L. Zhu and H. Fu, Org. Lett., 2012, 14, 452-455; (b) Q. Liao, X. Yang and C. Xi, J. Org. Chem., 2014, 79, 8507-8515; (c) M. L. Deb, S. S. Dey, I. Bento, M. T. Barros and C. D. Maycock, Angew. Chem., Int. Ed., 2013, 52, 9791-9795.

13 Y. Tang, C. Jiang, X. Zhang, C. Liu, J. Lin, Y. Wang, C. Du, X. Peng, W. Li, Y. Liu and M. Cheng, J. Org. Chem., 2017, 82, 11102-11109.

14 N. Panda and I. Mattan, RSC Adv., 2018, 8, 7716-7725. 